\title{
HUBUNGAN INDEKS MASSA TUBUH DENGAN DISMENOREA
}

\author{
Relationship Between Body Mass Index And Dysmenorrhea \\ Aris Widiyanto ${ }^{1}$, Anita Dewi Lieskusumastuti ${ }^{2}$, Sab'ngatun $^{3}$ \\ STIKES Mamba'ul 'Ulum Surakarta \\ (widiyanto.aris99@gmail.com)
}

\begin{abstract}
ABSTRAK
Latar Belakang : Kejadian dismenorea tertinggi pada remaja putri dengan perkiraan 20-90\%. Faktor risiko yang mempengaruhi terjadinya dismenorea salah satunya status gizi. Status gizi pada remaja dihitung dengan menggunakan rumus indeks massa tubuh (IMT). IMT tidak normal dapat disebabkan karena perubahan pola hidup dan pola makan sebagian remaja.

Tujuan : Penelitian ini bertujuan untuk mengetahui hubungan indeks massa tubuh dengan dismenore.

Metode : Metode penelitian ini adalah studi analitik dengan pendekatan potong lintang. Populasi penelitian ini adalah semua mahasiswi STIKES Mamba'ul 'Ulum Surakarta sebanyak 213 responden. Teknik pengambilan sampel menggunakan accidental sampling. Sampelnya adalah seluruh mahasiswi STIKES Mamba'ul 'Ulum Surakarta yang ditemui peneliti sebanyak 203 responden. Penelitian ini menggunakan alat pengumpul data berupa kuesioner. Analisa bivariat menggunakan Korelasi Spearman Rank.

Hasil : Karakteristik usia menarche, mayoritas adalah remaja awal (usia 10-13 tahun) sebanyak 142 responden (70\%), mayoritas lama haid $\leq 7$ hari sebanyak 164 responden (80,8\%) dan mayoritas siklus haid 28-35 hari sebanyak 138 responden (68\%). Distribusi frekuensi IMT mayoritas normal yaitu 129 responden $(63,5 \%)$ dan mayoritas dismenrorea ringan yaitu 105 responden $(51,7 \%)$. Hasil analisa Korelasi Spearman Rank diketahui nilai Signifikansi 0,180>0,05 maka tidak ada hubungan signifikan antara variabel IMT dengan dismenorea.
\end{abstract}

Simpulan: Tidak ada hubungan antara IMT dengan Dismenorea.

Kata kunci: IMT, Dismenorea.

\section{ABSTRACT}

Background: The highest incidence of dysmenorrhoea in young women with an estimate of 20-90\%. One of the risk factors that influence the occurrence of dysmenorrhea is nutritional status. The nutritional status of adolescents was calculated using the body mass index (BMI) formula. An abnormal BMI can be caused by changes in lifestyle and diet for some adolescents.

Purpose: This study aims to determine the relationship between body mass index and dysmenorrhea. 
Methods: This research method is an analytic study with a cross sectional approach. The population of this study were all students of STIKES Mamba'ul 'Ulum Surakarta as many as 213 respondents. The sampling technique used accidental sampling. The sample was all students of STIKES Mamba'ul 'Ulum Surakarta whom the researcher met, as many as 203 respondents. This study used a data collection tool in the form of a questionnaire. Bivariate analysis using Spearman Rank Correlation.

Results: Characteristics of the age of menarche, the majority were early adolescents (aged 10-13 years) as many as 142 respondents (70\%), the majority of menstrual duration $\leq 7$ days were 164 respondents (80.8\%) and the majority of menstrual cycles 28-35 days were 138 respondents (68\%). The majority of BMI frequency distribution was normal, namely 129 respondents (63.5\%) and the majority of mild dysmenrorea was 105 respondents (51.7\%). The results of the Spearman Rank Correlation analysis show that the significance value is 0.180> 0.05, so there is no significant relationship between the BMI variable and dysmenorrhoea.

Conclusion: There is no relationship between BMI and dysmenorrhoea.

Keywords: BMI, Dysmenorrhoea.

\section{PENDAHULUAN}

Wanita dari usia remaja yang tidak hamil hingga menjelang menopause mengalami haid setiap bulan. Nyeri perut dan rasa tidak nyaman dialami oleh banyak wanita pada saat haid yang dapat menyebabkan gangguan fisik seperti mual, lemas dan diare serta dapat mengganggu aktivitas dikenal dengan dismenorea (Pundati dkk, 2016).

Kejadian dismenorea tertinggi pada remaja putri dengan perkiraan 20-90\%, tergantung dari metode yang digunakan. Dismenore merupakan gangguan nyeri haid berupa kram perut yang dapat membatasi aktivitas wanita sehari-hari hingga memerlukan obat. Dismenorea yang paling sering terjadi adalah dismenorea primer, kemungkinan lebih dari 50\% wanita mengalaminya dan 10-15\% sebagian mengalami nyeri haid hebat sampai mengganggu aktivitas sehari-hari (Bahri dkk, 2015).

Dismenorea juga dialami wanita di Amerika Serikat yang diperikirakan 4590\%. Menurut data WHO didapatkan kejadian dismenorea sebesar 1.769.425 jiwa (90\%) (Herawati, 2017). Prevalensi dismenorea di Indonesia cukup tinggi yaitu $64,25 \%$ pada perempuan muda, yang terdiri dari 54,89\% dismenore primer dan 9,36\% dismenore sekunder (Bahri dkk, 2015). Tingginya angka tersebut diasumsikan dari berbagai gejala dismenorea yang belum dilaporkan. Sebagian besar wanita membeli obat sendiri dan tidak berkunjung ke dokter (Herawati, 2017).

Faktor risiko yang mempengaruhi terjadinya dismenorea antara lain faktor hormon, kekurangan gizi, merokok, status gizi, stress dan usia menarche 
(Anurogo dkk, 2011). Status gizi pada remaja dihitung dengan menggunakan rumus indeks massa tubuh. Indeks massa tubuh tidak normal (underweight dan overweight) dapat disebabkan karena perubahan pola hidup dan pola makan sebagian remaja. Pola makan tradisional mulai bergeser ke pola makan berat yang komposisinya tinggi kalori, lemak, karbohidrat dan kurang serat seperti fast food disertai dengan peningkatan pola hidup sedentary seperti kebiasaan bermain gadget, laptop yang mengakibatkan penurunan aktivitas fisik (Surur dkk, 2019). Status Gizi berkaitan erat dengan kejadian dismenorea. Hal ini didukung dengan penelitian Khotimah dkk, bahwa terdapat hubungan yang bermakna antara status gizi dengan dismenorea dengan nilai $\mathrm{p}$ value $=0,004<0,05$ (Khotimah $\mathrm{dkk}, 2018$ ).

Hasil studi pendahuluan diketahui bahwa sebagian remaja putri mahasiswa STIKES Mamba'ul 'Ulum Surakarta mengalami kram perut saat haid dan bahkan sebelum haid dengan tingkat nyeri yang berbeda baik cara penanganannya. Remaja putri yang mengalami dismenorea akan mengalami gangguan dalam aktivitas belajarnya karena merupakan kegiatan yang melibatkan kerja fisik dan juga otak. Menurut hasil penelitian sebelumnya, bahwa terganggunya aktivitas belajar mahasiswa akibat dismenore dapat meningkatkan frekuensi ketidakhadiran kuliah (Pundati dkk, 2016). Hasil penelitian sebelumnya juga menyebutkan bahwa terdapat hubungan signifikan antara indeks massa tubuh dengan derajat nyeri haid (dismenorea) pada remaja putri di SMA Negeri 21 Makassar diperoleh nilai $\mathrm{P}=0,001(\mathrm{P}<0,05)$ (Surur dkk, 2019).

Berdasarkan uraian diatas, penulis tertarik untuk melakukan penelitian dengan judul "Hubungan Indeks Massa Tubuh Dengan Dismenorea"

\section{METODE PENELITIAN}

Penelitian ini merupakan penelitian studi analitik dengan pendekatan potong lintang. Populasi penelitian ini adalah seluruh remaja putri mahasiswa STIKES Mamba'ul 'Ulum Surakarta tahun akademik 2019/2020 sejumlah 213 responden. Teknik pengambilan sampe menggunakan accident sampling. Sampel penelitian ini sebagian remaja putri mahasiswa STIKES Mamba'ul 'Ulum Surakarta tahun akademik 2019/2020 yang ditemui sebanyak 203 responden.

Pada penelitian ini menggunakan alat pengumpul data berupa kuesioner. Metode pengumpulan data yangdigunakan adalah pengumpulan data primer dan sekunder. Dalam penelitian ini pengumpulan data primer dilakukan dengan membagikan kuesioner secara langsung kepada responden, sedangkan pengumpulan data sekunder dilakukan dengan cara melihat dokumen-dokumen atau catatan-catatan yang mendukung data penelitian. Analisa data dalam penelitian ini menggunakan Korelasi Spearman Rank. 


\section{HASIL DAN PEMBAHASAN}

\section{Hasil}

Tabel 1 Distribusi Frekwensi Karakteristik Responden Berdasarkan Usia Menarche, Lama Haid dan Siklus Haid

\begin{tabular}{lcc}
\multicolumn{1}{c}{ Karakteristik } & Frekwensi (f) & Prosentase (\%) \\
\hline Usia Menarche & & \\
Remaja Awal (usia 10-13 tahun) & 142 & 70 \\
Remaja Tengah (14-16 tahun) & 58 & 28,6 \\
Remaja Akhir (17-18 tahun) & 3 & 1,5 \\
Total & 203 & 100 \\
Lama Haid & & \\
>7 hari & 39 & 19,2 \\
>7 hari & 164 & 80,8 \\
Total & 203 & 100 \\
Siklus Haid & & \\
<28 hari & 59 & 29 \\
28-35 hari & 138 & 68 \\
>35 hari & 6 & 3 \\
Total & 203 & 100 \\
\hline
\end{tabular}

Berdasarkan Tabel 1. menunjukkan karakteristik usia menarche, mayoritas adalah remaja awal (usia 10-13 tahun) sebanyak 142 responden (70\%), mayoritas lama haid adalah $\leq 7$ hari sebanyak 164 responden $(80,8 \%)$ dan mayoritas siklus haid 28-35 hari sebanyak 138 responden (68\%).

Tabel 2 Distribusi Frekuensi Variabel IMT

\begin{tabular}{ccc}
\hline IMT & Frekuensi (f) & Prosentase (\%) \\
\hline Obesitas $(>30)$ & 10 & 5 \\
Kegemukan $(25-29,9)$ & 29 & 14,3 \\
Normal $(18,5-24,9)$ & 129 & 63,5 \\
Kurus $(<18,5)$ & 35 & 17,2 \\
Total $(\mathrm{n})$ & 203 & 100 \\
\hline
\end{tabular}

Tabel 2 diatas menunjukkan bahwa indeks massa tubuh mahasiswi mayoritas dalam kategori normal yaitu 129 responden $(63,5 \%)$.

Tabel 3 Distribusi Frekuensi Variabel Dismenorea

\begin{tabular}{ccc}
\hline IMT & Frekuensi (f) & Prosentase (\%) \\
\hline Dismenorea Berat & 28 & 18,7 \\
Dismenorea Sedang & 22 & 11 \\
Dismenorea Ringan & 105 & 51,7 \\
Tidak Dismenorea & 38 & 18,7 \\
Total (n) & 203 & 100 \\
\hline
\end{tabular}

Tabel 3 diatas menunjukkan bahwa kejadian dismenorea pada mahasiswi mayoritas dalam kategori dismenrorea ringan yaitu 105 responden $(51,7 \%)$ 
Tabel 4 Tabulasi Silang IMT dan Dismenorea

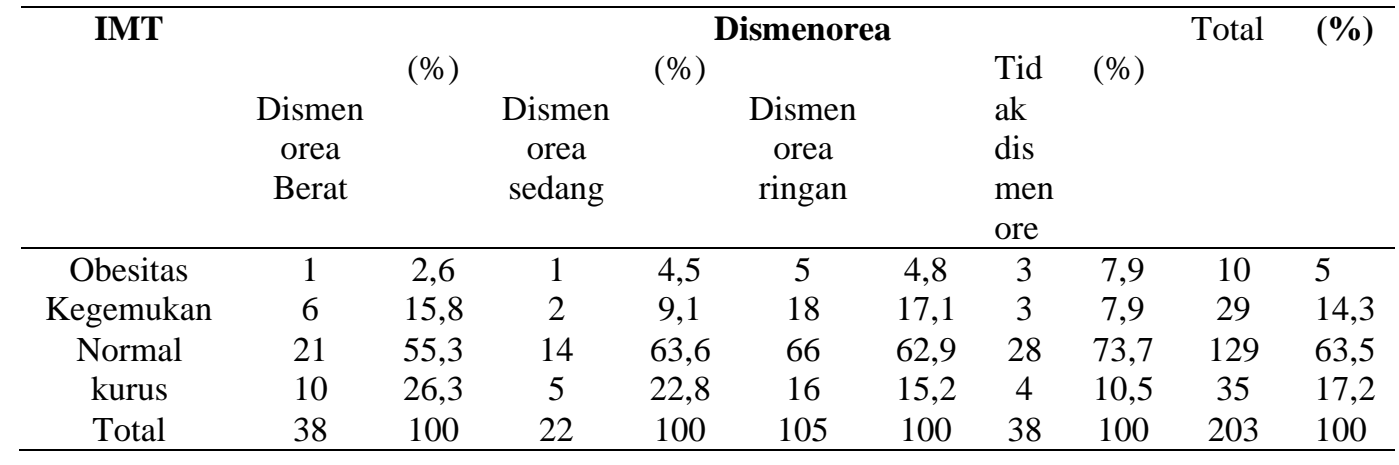

Berdasarkan tabel 4 diketahui bahwa mayoritas responden dengan IMT Normal termasuk kategori dismenorea ringan sebanyak 66 responden $(62,9 \%)$.

Tabel 5. Analisa Bivariat Spearman Rank Hubungan IMT dan Dismenorea

\begin{tabular}{lllrr}
\hline \multicolumn{4}{c}{ Correlations } \\
\hline Spearman's rho & IMT & Correlation Coefficient & 1.000 & -.094 \\
& & Sig. (2-tailed) &. & .180 \\
& & $\mathrm{~N}$ & 203 & 203 \\
& \multirow{2}{*}{ Dismenorea } & Correlation Coefficient & -.094 & 1.000 \\
& & Sig. (2-tailed) & .180 &. \\
& & $\mathrm{~N}$ & 203 & 203 \\
\hline
\end{tabular}

Berdasarkan tabel 5 diketahui hasil analisa Korelasi Spearman Rank diketahui nilai Signifikansi (2-tailed) yaitu 0,180 >0,05 maka tidak ada hubungan yang signifikan (berarti) antara variabel IMT dengan dismenorea. Maka $\mathrm{H}_{0}$ diterima dan $\mathrm{H}_{\mathrm{a}}$ ditolak. Jadi tidak ada hubungan antara IMT dengan Dismenorea.

\section{Pembahasan}

Tabel 1 menyebutkan hasil data pola haid meliputi usia menarche, lama haid dan siklus haid. Data usia menarche pada responden, mayoritas adalah remaja awal (usia 10-13 tahun). Hal ini didukung oleh penelitian Barcikowska, et all bahwa wanita yang mendapat menstruasi pertama kali pada usia $\leq 12$ tahun sebanyak 542 (48\%) (Barcikowska et all, 2020). Usia menarche biasanya terjadi pada usia 12-13 tahun (Waryana, 2010). Menarche adalah menstruasi pertama terjadi yang merupakan ciri khas kedewasaan seorang wanita yang sehat dan tidak hamil. Status gizi remaja mempengaruhi terjadinya menarche baik dari faktor usia terjadinya menarche, adanya keluhan-keluhan selama menarche maupun lamanya hari menarche. Usia gadis remaja pada waktu pertama kalinya mendapat menstruasi (menarche) bervariasi lebar, yaitu antara 10-16 tahun, tetapi rata- 
ratanya 12,5 tahun. Statistic menunjukan bahwa usia menarche dipengaruhi oleh factor keturunan, keadaan gizi dan kesehatan umum (Anurogo dan Wulandari 2011). Hormon yang berpengaruh terhadap terjadinya menarche adalah estrogen dan progesterone. Estrogen berfungsi mengatur siklus haid sedangkan progesterone berpengaruh pada uterus yaitu dapat mengurangi kontraksi selama siklus haid (Waryana, 2010).

Hubungan yang signifikan antara usia dini menarke dan dismenore ditemukan dalam penelitian Al-Matouq et all (2019) dimana menarke dini mencerminkan paparan prostaglandin lebih lama berperan besar dalam dismenorea melalui peningkatan kontraksi uterus yang menyebabkan nyeri. Hasil penelitian Mutasya (2013) responden yang memiliki status gizi normal dan kegemukkan lebih banyak mengalami menarche di bawah usia 13 tahun, sedangkan yang mengalami menarche di atas usia 13 tahun lebih banyak responden dengan status gizi kurus. Dari uji statistik didapatkan nilai $\mathrm{p}=0,018$ yang berarti terdapat hubungan yang bermakna antara status gizi dengan usia menarche. Status gizi remaja putri sangat mempengaruhi terjadinya menarche baik dari faktor terjadinya menarche, adanya keluhan selama menstruasi, maupun lamanya hari menstruasi.

Berdasarkan hasil penelitian ini menunjukkan bahwa lama haid responden mayoritas adalah $\leq 7$ hari. Hasil ini sejalan dengan Penelitian Pundati (2016) bahwa mayoritas responden mempunyai lama menstruasi $\leq 7$ hari sebanyak $55,3 \%$. Lamanya menstruasi sekitar 2-8 hari dan rata-rata 4-6 hari (Waryana, 2010). Siklus menstruasi adalah serangkaian periode perubahan yang terjadi berulang pada uterus dan organ-organ yang dihubungkan pada saat pubertas dan berakhir pada saat menopause. Jarak siklus menstruasi bervariasi antara 15-45 hari dan rata-rata 28 hari (Waryana, 2010). Pada penelitian ini menunjukkan bahwa sebagian besar responden siklus haidnya 28-35 hari. Jarak siklus menstruasi pendek ( $<21$ hari) dan panjang ( $>35$ hari) dapat dikatakan abnormal (Syafrudin, 2011). Penelitian lain menunjukkan siklus responden paling banyak adalah siklus normal (25-32 hari) yaitu 103 responden (80,5\%) (Sirait, 2014).

Tabel 2 menunjukkan bahwa sebagian besar responden termasuk dalam kategori IMT normal. Hal ini didukung oleh penelitian Barcikowska, et all bahwa mayoritas wanita yang berpartisipasi dalam penelitiannya dengan IMT 18,5-24,9 $\mathrm{kg} / \mathrm{m}^{2}$. Nilai tersebut merupakan berat badan normal dan hanya sedikit responden yang IMT-nya mengindikasikan kelebihan berat badan atau kelebihan berat badan (Barcikowska et all, 2020). Penelitian ini sejalan dengan penelitian Helwa (2018) bahwa mayoritas partisipan sebanyak $75,4 \%$ adalah IMT normal. Wanita yang memiliki berat badan berlebih memiliki resiko dua kali lebih kuat mengalami nyeri menstruasi daripada wanita yang berat badan normal. Sedangkan status gizi yang kurang dapat memperparah keadaan dismenorea tersebut (Anurogo dan Wulandari 2011).

Status gizi atau dikatakan baik, apabila nutrisi yang diperlukan baik protein, lemak, karbohidrat, mineral, vitamin maupun air digunakan oleh tubuh sesuai kebutuhan. Gizi kurang atau terbatas selain akan mempengaruhi 
pertumbuhan, fungsi organ tubuh juga akan menyebabkan terganggunya fungsi reproduksi. Hal ini akan berdampak pada gangguan haid, tetapi membaik bila asupan nutrisinya baik (Khotimah dkk, 2018). Kekurangan zat gizi makro, seperti essensial fatty acid akan memicu dismenorea, karena essensial fatty acid ini berfungsi sebagai bahan awal untuk mengatur hormon molekul seperti molekul (prostaglandin) yang mengatur aktivitas sel (Anurogo dan Wulandari 2011).

Pada penelitian ini, responden yang mengalami dismenorea sebanyak 81,3\% meliputi dismenorea ringan, sedang dan berat, dimana mayoritas responden mengalami dismenorea ringan. Hasil ini didukung oleh penelitian Pundati (2016) bahwa klasifikasi dismenorea pada responden mayoritas adalah dismenorea ringan (49,4\%). Penelitian Barcikowska (2020) juga menemukan bahwa kejadian dismenorea pada responden sebanyak 94\%. Dismenorea ringan merupakan rasa nyeri yang berlangsung beberapa saat sehingga perlu istirahat sejenak untuk menghilangkan nyeri tanpa disertai pemakaian obat. Setiap menstruasi menyebabkan rasa nyeri, terutama pada awal menstruasi namun dengan kadar nyeri yang berbeda-beda (Prawirohardjo,2011). Hasil penelitian Pundati (2016) Analisis statistik Univariat menunjukkan bahwa $67,1 \%$ responden mengalami dismenore. Analisis statistik bivariat dengan uji chi-square menunjukkan bahwa ada hubungan yang signifikan antara menstruasi dan dismenore pada siswa semester 8 dengan $\mathrm{p}=0,03$ ( $\mathrm{p}<0,05)$; Ada hubungan yang signifikan antara tingkat stres dan kejadian dismenore pada siswa semester 8 dengan $p=0,023$ ( $p$ > $0,05)$. Faktor yang paling dominan menyebabkan disminore adalah stres.

Secara umum, seseorang akan merasakan nyeri haid yang disebabkan karena rendahnya hormon progesteron dan estrogen pada akhir luteum, kemudian terjadi peningkatan sintesis prostaglandin dan terjadi vasokontriksi pembuluh darah arteri spiralis. Selanjutnya memberikan dampak iskemik endometrium bagian kompakta, dan spongiosa sehingga terjadi nekrosis. Kontraksi otot uterus yang makin kuat kemudian menjepit ujung saraf, rangsangannya dialirkan melalui serat saraf simpatikus dan para simpatikus dan dirasakanlah nyeri haid(Surur dkk, 2019). Menurut Prawirohardjo (2011), dismenorea memiliki gejala seperti nyeri perut timbul sebelum atau selama menstruasi, nyeri kepala, mual, muntah, sembelit atau diare, sering berkemih, pegal-pegal dan nyeri otot, nyeri pinggang bawah, sensitive, irribilitas, dan rasa lelah. Pada penelitian ini diketahui bahwa sebagian remaja putri menggunakan pengobatan anti nyeri pada saat mengalami dismenorea bahkan sampai meninggalkan aktivitasnya seharian. Peneliti lain manyatakan bahwa dismenorea pada remaja putri berdampak pada kegiatan aktivitas sehari-hari (Mohapatra, 2016).

Hasil analisa bivariat pada penelitian ini menunjukkan bahwa tidak ada hubungan antara IMT dengan Dismenorea. Hasil ini sejalan dengan penelitian Helwa (2018) bahwa tidak ada hubungan antara IMT dan Dismenorea dengan nilai p 0,099>0,005. Peneliti Vlachou (2019) juga menunjukkan bahwa tidak ada perbedaan yang signifikan pada merokok, olahraga, body mass index (BMI) dan durasi siklus menstruasi pada kelompok nyeri ringan, nyeri sedang, nyeri berat, dan tanpa nyeri ( $p>0,1)$. Penelitian Barcikowska (2020) menyatakan bahwa tidak 
ada hubungan yang signifikan antara IMT dan Dismenorea $(\mathrm{p}=0,271)$. Status gizi underweight dan overweight jika dibandingkan dengan status gizi normal, hasilnya tidak ada hubungan yang bermakna antara status gizi dengan dismenorea (Sirait, 2014).

Hasil penelitian ini tidak sejalan dengan penelitian lain bahwa terdapat hubungan yang bermakna antara status gizi dengan dismenorea dengan nilai $\mathrm{p}$ value $=0,004<0,05$. (Khotimah $\mathrm{dkk}$, 2018) Hasil penelitian sebelumnya juga menyebutkan bahwa terdapat hubungan signifikan antara indeks massa tubuh dengan derajat nyeri haid (dismenorea) pada remaja putri di SMA Negeri 21 Makassar diperoleh nilai $\mathrm{P}=0,001(\mathrm{P}<0,05)$. (Surur dkk, 2019) Sistem reproduksi seorang wanita tidak akan mengalami hambatan apabila status gizinya baik. IMT dapat digunakan untuk mengetahui status gizi pada remaja melalui gambaran proporsi ideal tubuh seseorang antara berat badan saat ini terhadap tinggi badan yang dimilikinya. Apabila kekurangan nutrisi akan berdampak pada penurunan fungsi reproduksi yang menyebabkan perubahan hormon-hormon tertentu dalam tubuh yang berhubungan dengan gangguan fungsi hypothalamus akibatnya perubahan siklus ovulasi dan menstruasi (Sibagariang, 2010). Biasanya dismenorea terjadi dalam beberapa jam awal menstruasi dan peningkatan aliran maksimal selama 1 atau 2 hari. Etiologi dan patofisiologi dismenore primer tidak sepenuhnya diketahui, tetapi kebanyakan gejala disebabkan oleh aktivitas prostaglandin uterus, khususnya PGF2 $\alpha$ dilepaskan dari sel-sel endometrium yang hancur saat mesntruasi dimulai. PGF $2 \alpha$ merangsang kontraksi miometrik, iskemia dan sensitisasi ujung saraf. Bukti dari teori ini adalah bahwa wanita dengan dismenorea yang berat memiliki tingkat PGF2 $\alpha$ dalam darah menstruasi (Mohapatra, 2016).

Beberapa penelitian menunjukkan bahwa IMT yang abnormal dapat mempengaruhi wanita untuk mengalami dismenorea. Wanita yang memiliki akumulasi jaringan lemak visceral yang signifikan, paling sering mengalami periode menstruasi yang menyakitkan. Namun, IMT tidak mampu menggambarkan proporsi lemak yang terkandung di dalam tubuh seseorang (Barcikowska, 2020). IMT merupakan salah satu cara penilaian status gizi pada remaja. Penilaian status gizi remaja harus dilakukan secara berkala agar diketahui status gizi remaja dan tindakan dapat segera dilakukan untuk mengembalikan remaja ke dalam status gizi baik, sehingga perkembangan system reproduksi remaja berkembang dengan sebagaimana mestinya. Status gizi baik pada remaja dapat diperoleh dengan konsumsi gizi seimbang sesuai kebutuhan pada masa remaja (Fairuz, 2010). Faktor lain yang berhubungan dengan dismenorea menurut penelitian lain adalah riwayat dismenorea dari ibu dan saudara perempuan, pre menstruasi syndrome (PMS), usia menarche, stress, latihan fisik (Barcikowska, 2020), keteraturan siklus menstruasi, pendidikan ibu (Helwa, 2018) sedangkan beberapa hal yang mempengaruhi status gizi selain IMT yang berhubungan dengan kejadian dismenorea meliputi konsumsi harian makanan manis (Nakame, 2019), sarapan pagi (Helwa, 2018), minum kopi mingguan (Al Matouq,2019) merokok, alcohol (Ju, 2015). 


\section{SIMPULAN DAN SARAN}

\section{Simpulan}

Karakteristik responden mayoritas adalah menarche pada usia remaja awal, lama haid $\leq 7$ hari dan siklus haid 28-35 hari. Mayoritas reponden mempunyai IMT normal dan mengalami dismenorea ringan. Pada penelitian ini disimpulkan bahwa tidak ada hubungan IMT dengan dismenorea.

\section{Saran}

Bagi remaja putri khususnya tetap menjaga asupan nutrisi yang seimbang sehingga berat badan ideal dan status gizi baik. Menggunakan metode non pengobatan untuk mengatasi nyeri haid atau dismenore yang dialami. Bagi Institusi pendidikan diharapkan tetap memfasilitasi mahasiswa untuk memantau IMT secara berkala dan rutin.

\section{DAFTAR PUSTAKA}

Al-Matouq, Sharefah, Hessah AM, Ohood AM, Fatima A, Dana AB, Mona AE dan Abdullah AT. 2019. Dysmenorrhea among high-scholl students and its associated factors in Kuwait. BMC Pediatric 2019;19:80. http://doi.org/10.1186/s12887-019-1442-6

Anurogo, D \& Wulandari, Ari.2011. Cara Jitu Mengatasi Nyeri Haid. Yogyakarta: Andi Offset

Aprilianti, C., \& Ghia, A. 2020. The Asupan Kalsium dan Kejadian Dismenore pada Remaja. Jurnal Ilmiah Permas: Jurnal Ilmiah STIKES Kendal, 10(1), 91-96.

http://journal.stikeskendal.ac.id/index.php/PSKM/article/download/658/400

Bahri, A. A., Afriwardi, A., \& Yusrawati, Y. 2015. Hubungan antara Kebiasaan Olahraga dengan Dismenore pada Mahasiswi Pre-Klinik Program Studi Pendidikan Dokter Fakultas Kedokteran Universitas Andalas Tahun Ajaran 2012-2013. Jurnal Kesehatan Andalas, 4(3). http://jurnal.fk.unand.ac.id/index.php/jka/article/view/369

Barcikowska, Z, Karolina WB, Agnieszka SR, Magdalena EG, Piotr W dan Katarzyna Z. 2020. Dysmenorrhea and Associated Factors among Polish Women: A Cross-Sectional Study. Pain Research and Management. 2020; $2020: 6161536$. https://doi.org/10.1155/2020/6161536

Fairuz, M dan Prasetyowati. 2010. Buku Saku Gizi \& Kesehatan Reproduksi. Jakarta: EGC.

Helwa, HAA, Areen AM, Suha AH, Waleed MS. 2018. Prevalence of dysmenorrheal and predictors of its pain intensity among Palestinian female university student. BMC Women's Health 2018; 18:18. http://doi.org/10.1186/s12905-0516-1 
Herawati, R. 2017. Faktor-Faktor yang Mempengaruhi Kejadian Nyeri Haid (Dismenorea) pada Siswi Madrasah Aliyah Negeri Pasir Pengaraian. Jurnal Martenity and Neonatal, 2(3), 161-172. http://ejournal.upp.ac.id/index.php/akbd/article/download/1382/1107

Khotimah, S., \& Wahyuni, L. (2018). Analisis Faktor Yang Berhubungan Dengan Kejadian Dismenorea Pada Remaja Putri. In Prosiding Seminar Nasional Teknopreneur Universitas Pasir Pengaraian (Vol. 1, No. 1, pp. 422-427). http://eproceedings.upp.ac.id/index.php/Semnasteknopreneur/article/download/191 174

$\mathrm{Ju}, \mathrm{H}$, Mark J, Gita DM. 2015. A U-Shaped Relationship between Body Mass Index and Dysmenorrhea: A Longitudinal Study. PLoS One. 2015; 10(7): e0134187. https://doi.org/10.1371/journal.pone.0134187

Mohapatra,D, Tapaswini M, Manasi B, Priyambada P. 2016. A Study of Relation Beetween Body Mass index and Dysmenorrhea and its impact on daily activities of medical students. Asian Journal of Pharmaceutical and clinical research, Vol 9 , Suppl.3,297-299. https://www.researchgate.net/profile/Tapaswini_Mishra/publication/315959 602_A_study_of_relation_between_body_mass_index_and_dysmenorrhea and_its_impact_on_daily_activities_of_medical_students/links/59bd00afa6f dcca8e567aa90/A-study-of-relation-between-body-mass-index-anddysmenorrhea-and-its-impact-on-daily-activities-of-medical-students.pdf

Mutasya, FU, Edison, Hasnar H. 2013. Faktor-Faktor Yang Berhubungan dengan Usia Menarche Siswi SMP Adabiah. Jurnal Kesehatan Andalas 2016:5(1) http://jurnal.fk.unand.ac.id/index.php/jka/article/view/475/403

Nakame RM, Kiwanuka F, Robert A. 2019. Dysmenorrhoea among students aged 18-45 years attending University in Uganda: A cross-sectional multicenter study of three Universities in Uganda. Nursing Open,2019;6:268-275. https://doi.org/10.1002/nop2.207

Pundati, TM, Colti S, Bambang H. 2016. Faktor-faktor Yang Berhubungan dengan Kejadian Dismenorea pada Mahasiswa Semester VIII Universitas Jenderal Soedirman Purwokerto. Jurnal Kesmas Indonesia Voume 8 No 1 $\begin{array}{llll}\text { Januari } & 2016 & \text { Hal } & \text { 40-48. }\end{array}$ http://jos.unsoed.ac.id/index.php/kesmasindo/article/download/140/129/

Pradana, A., Seno, K., \& Puruhita, N. 201). Hubungan antara Indeks Massa Tubuh (IMT) dengan Nilai Lemak Viseral (Studi Kasus pada Mahasiswa Kedokteran Undip) (Doctoral dissertation, Faculty of Medicine Diponegoro University).

http://eprints.undip.ac.id/44412/9/ADHITYA_PRADANA_2201011012006 4_BAB_8_KTI.pdf

Prawirohardjo, Sarwono. 2011. Ilmu Kandungan. Jakarta : PT Bina Pustaka Sarwono Prawirohardjo 
Pundati, TM, Colti S, Bambang H. 2016. Faktor-Faktor Yang Berhubungan Dengan Kejadian Dismenorea Pada Mahasiswa Semester VIII Universitas Jenderal Soedirman Purwokerto. Jurnal Kesmas Indonesia Volume 8 No 1, $\begin{array}{lll}\text { Januari } & \text { 2016, Hal 40-48 }\end{array}$ http://jos.unsoed.ac.id/index.php/kesmasindo/article/download/140/129/.

Sibagariang, EE. 2010. Gizi dalam Kesehatan Reproduksi. Jakarta: TIM

Sirait, DSO, Hiswani, Jemadi. 2014. Faktor-faktor yang berhubungan dengan kejadian dismenore pada siswi SMA Negeri 2 Medan Tahun 2014. Jurnal $\begin{array}{lllll}\text { USU } & \text { Volume } & 1 & \text { No } & 4 .\end{array}$ https://jurnal.usu.ac.id/index.php/gkre/article/view/8583/4353

Surur, A. Z., Putri, M., \& Multazam, A. F. 2019. Body Mass Index and Dysmenorrhea in Female Teenagers. Indonesian Contemporary Nursing Journal, 4(1), 21-26. http://journal.unhas.ac.id/index.php/icon/article/download/6705/4366

Syafrudin, Ayi DD. 2011. Himpunan Penyuluhan Kesehatan (Pada Remaja, Keluarga, Lansia dan Masyarakat). Jakarta: Trans Info Media.

Vlachou, E, et all. 2019. Prevalence, Wellbeing, and Symptoms of Dysmenorrhea among University Nursing Students in Greece. Diseases 2019 Mar, 7(1):5. http://doi.org/10.3390/diseases7010005

Waryana. 2010. Gizi Reproduksi. Yogyakarta: P 